\title{
KEARIFAN LOKAL MASYARAKAT DESA MBAWA DALAM MEWUJUDKAN TOLERANSI BERAGAMA
}

\section{LOCAL WISDOM OF MBAWA VILLAGE SOCIETY IN BUILDING RELIGIOUS TOLERANCE}

\author{
I Made Purna \\ Balai Pelestarian Nilai Budaya Bali, NTB, NTT \\ Jl. Raya Dalung Abianbase No. 107 Kuta Utara Badng Bali \\ e-mail: purna.bpsnt@gmail.com
}

Naskah diterima tanggal:27/8/2015, direvisi akhir tanggal: 14/7/2016, disetujui tanggal:29/8/2016

\begin{abstract}
Donggo is an ethnic community living in Mbawa Village, District Donggo, Bima, West Nusa Tenggara. This Ethnic consists of various monotheism religions, such as Islam, Catholic, and Protestant. Despite having a plural society background from various religions, Donggo's community in Mbawa village have capability in maintaining the harmony among their community. This study aims to analyze how the community in Mbawa village with various religions can avoid religious-based conflict. In addition, it analyzes what strategies are used to achieve the harmony among the community of Mbawa village. Observation was used as the main method of this study. The results of this study shows that in maintaining harmony among religious people in their community, people of Mbawa village apply their local knowledge as a cultural strategy to avoid religious conflict. In summary, local wisdom in Mbawa Village can bridge the community members of different religious beliefs.
\end{abstract}

Keywords: strategy of harmony, local wisdom, religious tolerance

\begin{abstract}
Abstrak: Masyarakat Donggo merupakan sebuah etnis yang mendiami Desa Mbawa, Kecamatan Donggo, Kabupaten Bima, Nusa Tenggara Barat. Etnis ini terdiri atas berbagai macam penganut agama monoteis seperti Islam, Khatolik dan Protestan. Dengan latar belakang masyarakat majemuk yang terdiri dari berbagai macam agama, masyarakat Donggo di Desa Mbawa dapat memelihara harmonisasi antaranggota masyarakat. Tujuan penelitian ini dimaksudkan untuk mengkaji bagaimana masyarakat Desa Mbawa yang terdiri atas berbagai macam penganut agama dapat menghindari konflik berbasis agama. Selain itu, strategi apa saja yang digunakan sebagai wahana mewujudkan keharmonisan masyarakat Desa Mbawa. Metode observasi digunakan sebagai tumpuan utama dalam penelitian ini. Hasil dari penelitian ini menunjukkan bahwa dalam menjaga kerukunan antarumat, masyarakat Desa Mbawa menggunakan kearifan lokal sebagai strategi budaya untuk menghindari terjadinya konflik antarumat. Penelitian ini menyimpulkan bahwa kearifan lokal yang hidup di Desa Mbasa mampu menjembatani anggota masyarakat yang berbeda keyakinan.
\end{abstract}

Kata kunci: strategi kerukunan, kearifan lokal, toleransi beragama 


\section{PENDAHULUAN}

Pengentasan kemiskinan, ketertinggalan, dan keterpurukan dalam pembangunan akibat hubungan antarwarga negara menjadi masalah yang krusial dan senantiasa menyita perhatian pemerintah dan masyarakat Indonesia. Terlebih dalam pembangunan untuk mewujudkan keharmonisan antaretnik, antarpemeluk agama monoteis dan antarkepercayaan asli serta kebudayaan setempat sebagai bagian dari identitas mereka. Cita-cita akan terciptanya suatu masyarakat bangsa yang kukuh dan integral, modern, maju, berkarakter, beridentitas, demokratis, sejahtera, serta menghindari konflik terus menantang. Aneka solusi telah ditawarkan lewat berbagai pendekatan maupun strategi antara lain: politik, sosial, ekonomi, religius, kebudayaan dengan revolusi mental sebagai pendekatan terbaru dalam kebudayaan (Purwanto, 2015).

Konflik antarpemeluk yang berbeda agama dan antaretnik di Indonesia baik yang dicirikan oleh persaingan untuk mencari pendukung maupun persaingan untuk kemurnian dan keaslian dari ajaran agama selalu muncul, baik secara terlihat maupun laten. Dengan etnis yang sama, perbedaan agama sudah rentan untuk konflik. Bagi pemeluk agama yang berbeda dan etnik yang berbeda persaingan akan semakin tajam (Purna, 2007). Negara Kesatuan Republik Indonesia (NKRI) sudah berkomitmen bahwa modal dasar multikultur dan multiagama itu harus dikemas dengan sikap toleransi dan jiwa integrasi (Sudarma, 2007)

Ramalan Huntington (dalam Tule, 2010) tentang benturan peradaban (class of civilization) nampaknya dibenarkan oleh adanya benturan antara Islam melawan Kristen, Katholik melawan Kristen, Hindu melawan Khatolik, dan lain-lain di pelbagai belahan dunia. Konflik yang berdampak negatif untuk pembangunan itu juga terjadi pada saat fanatisme agama cenderung mengkafirkan kebudayaan lokal dalam hal ini adalah kearifan lokal.

Tulisan ini menawarkan suatu Strategi Kebudayaan, terutama kearifan lokal setempat untuk melanggengkan dan mendayagunakan nilai-nilai budaya berbasis "rumah" sebagai wahana harmonisasi antaranggota masyarakat majemuk, terutama kemajemukan dari segi agama dan keyakinan untuk menuju pembangunan dan kesejahteraan serta kebahagiaan sebagaimana yang dialami etnis Donggo yang berada di Desa Mbawa, Kecamatan Donggo, Kabupaten Bima, NTB. Ada tiga agama yang berkembang di Desa Mbawa, yaitu Islam, Khatolik dan Protestan. Dari ketiga agama tersebut, mayoritas penduduk Desa Mbawa menganut Islam. Meski sudah menganut agamaagama monoteis, pada kenyataannya dari seluruh pemeluk agama-agama monoteis tersebut masih menjunjung tinggi kepercayaan asli dan budaya setempat sebagai penyatuan dan identitas mereka. Konsep kosmologis yang mengagungkan harmoni dengan tanah yang etnis Donggo tempati dan tanami serta keyakinan yang dianut, bahwa arwah para leluhur hadir dalam aneka monumen budaya, rumah adat, upacara tradisional, pemberian identitas nama seseorang, warga Etnis Donggo, pada tataran tertentu telah menjembatani jurang dan malah memperkecil konflik di Desa Mbawa. Pada tahun 1969 pernah terjadi konflik antarumat beragama hingga terjadi pembakaran beberapa rumah lantaran dipicu isu pencurian sandal milik umat Islam. Peristiwa tersebut sudah menjurus ke masalah sara, yaitu penghancuran gedung gereja dan pasturnya diusir keluar dari Desa Mbawa.

Atas dasar dari pengalaman akan nilai budaya lokal etnis Donggo yang positif dan konstruktif, otonomi kebudayaan lokal terutama kebudayaan yang mengandung pesan-pesan kearifan lokal baik dalam level institusional maupun populer akan dikemukakan sebagai prasayarat mutlak dalam mempertahankan keberadaan mulai dari etnik Donggo dan Negara Kesatuan Republik Indonesia (NKRI) demi perwujudan pembangunan kesejahteraan dan kebahagiaan yang dilandasi oleh dasar negara Pancasila, sebagai penengah, pengendali dan rujukan budaya warga negara Indonesia. Di 
tengah isu radikalisme yang mengemuka dengan tertangkapnya beberapa orang yang diduga teroris yang berasal dari Bima khususnya dan di Indonesia umumnya, perlu ditanamkan kesadaran perdamaian, toleransi dan cinta sesama manusia dengan merujuk pada potensi kearifan lokal sebagai sumber penyatuan. Dalam rangka mempertahankan rasa persatuan dan kebangsaan tidak perlu membangkitkan fanatisme yang berlebihan. Masyarakat muslim tidak perlu merasa kurang kemuslimannya, yang Khatolik tidak perlu kurang kekhatolikannya, yang Protestan tidak perlu kurang keprotestanannya, yang etnik Toraja tidak kurang ketorajaannya dan penganut Kejawen tidak perlu menyembunyi kan penghayatannya. Bibit kekerasan atas nama agama sudah ada sejak dua dekade terakhir. Muncul ekspansi Islam yang mendukung kekerasan hingga aksi terorisme. Pesantren dituduh sebagai penyemai bibit radikalisme. Padahal, para Kyai umumnya memahami keberagaman seperti Indonesia dengan rendah hati.

Bertitik tolak dari urain tersebut di atas, maka tulisan ini akan membatasi pembahasan antara lain: a) Mengapa pada masyarakat Desa Mbawa selama empat dasa warsa ini tidak pernah terjadi konflik. Potensi untuk konflik sangat memungkinkan karena dari ketiga agama yang hidup dan berkembang di Desa Mbawa adalah tipe agama yang mengajak maupun menarik umat lain. Dengan kata lain, agama yang ada di Desa Mbawa memiliki misi untuk melakukan pencarian umat sebanyak mungkin. Terlebih lagi kehadiran agama Islam, Khatolik dan Protestan di tengah-tengah masyarakat yang tadinya dikategorikan kafir; b) Tulisan ini juga menggali strategi apa saja yang dipakai sebagai landasan agar keharmonisan tetap terjaga. Walaupun dewasa ini tidak sedikit kelompok agama yang menginformasikan pemikiran tentang pemurnian agama selalu hadir lewat kelompok-kelompok aliran keagamaan dari ketiga agama yang tumbuh dan berkembang di Desa Mbawa.
Sejalan dengan permasalahan tersebut, penelitian ini bertujuan untuk mengidentifikasi dan mengkaji tentang: a) Bagaimana masyarakat Desa Mbawa yang terdiri dari berbagai macam penganut agama seperti Islam, Khatolik dan Protestan dapat menghindari konflik berbasis agama; dan b) Strategi apa yang digunakan sebagai landasan dalam menjaga keharmonisan di lingkungan sosial masyarakat Desa Mbawa.

\section{KAJIAN LITERATUR}

Strategi itu seperti air, demikian kata Sun Tsu seorang ahli strategi yang hidup 500 SM di negeri Cina. Lebih jauh Sun Tsu mengatakan, di dalam kolam, air mengikuti bentuk kolam, di sungai air mengikuti sungai. Di lautan air bisa menutupi samudra (Confido, 2015), begitu pula dengan strategi, tidak ada yang baku. Pada hakikatnya tidak ada suatu strategi yang tepat di suatu situasi. Jika ada yang hanya menyalin atau meniru bisa gagal bila tidak dipahami dengan benar, mengapa strategi yang ditiru tersebut bisa berhasil pada saat diterapkan oleh pembuatnya.

Walaupun strategi tidak ada yang baku dan sebagian ahli berpendapat strategi mengandung unsur seni, dan tidak bisa diberi nilai, apakah suatu strategi merupakan strategi yang baik ataukah sebaliknya. Minimal ada tiga kriteria yang dapat digunakan untuk menilai sebuah strategi yaitu moral, hasil, dan sumber daya. Strategi yang baik adalah strategi yang bermoral dalam pengertian sesuai dengan nilai-nilai yang berlaku pada masyarakat setempat. Strategi yang baik, tentunya strategi yang membawa hasil yang diinginkan. Sebaik apapun strategi tidak ada gunanya bila tidak memberikan hasil yang diinginkan. Strategi yang baik juga harus menggunakan sumber daya yang sehemat mungkin. Meskipun hasil yang diinginkan bisa diperoleh, akan tetapi bila pengorbanan sumber daya yang dikeluarkan terlalu besar, maka strategi tersebut merupakan strategi yang buruk. 
Strategi merupakan buatan manusia yang berbudaya, bermoral, dan selalu dinamis mengikuti situasi jaman. Budayawan Van Peursen dalam bukunya Strategi Kebudayaan mengutip filsuf Jerman Immanuel Kant, menyatakan bahwa, ciri khas kebudayaan terdapat dalam kemampuan manusia untuk mengajar dirinya sendiri. Kebudayaan merupakan semacam sekolah yang mewadahi manusia agar dapat terus-menerus belajar (Van Peursen, 1989). Dengan demikian, proses belajar seumur hidup (life long learning) harus menjadi ciri pendidikan di 'sekolah kebudayaan' ini. Sebaliknya, manusia sepanjang hidupnya senantiasa terlibat dalam proses interaksi dan bahkan konflik (ketegangan) antardirinya dengan sesama dan aneka kekuatan lain dalam berbagai aspek kehidupannya.

Van Peursen mengatakan bahwa dengan pendekatan kebudayaan yang struktural dan fungsional, suatu model kebudayaan terdiri dari: mitologis, ontologis dan fungsional, yang pada implementasi sebaiknya serentak bersifat progresif dan integral antara ketiganya. Kebudayaan harus terus-menerus menjadi dasar suatu strategi maupun rencana yang harus dibuat guna membebaskan manusia dari penjara yang dibuat oleh manusia sendiri melalui kreatifitas etis dan pembaharuan yang infenting (Van Peursen, 1989). Pandangan Van Peursen tentang pembangunan kebudayaan sangat tepat untuk Indonesia yang bercirikan pluralisme kebudayaan dengan jumlah 604 etnis. Pandangan Van Peursen akan menunjang kebudayaan-kebudayaan lokal (daerah) untuk secara sadar berada (eksis) dan berperan dalam proses kristalisasi kebudayaan nasional dan pembangunan bangsa pada umumnya dan hidup harmonis dengan bertoleransi dalam kemajemukan budaya dan agama. Abad ke-21 merupakan abad revitalisasi kebudayaan, restorasi sosial dan dialog peradaban. Huntington (1996) sudah memberi sinyal tampil dengan paradigma alternatif, yakni pendekatan peradaban civilization approach terhadap situasi politik global pada akhir abad ke-20 dan awal abad ke-21, di mana pada awal abad-21 merupakan abad revitalisasi kebu-dayaan, restorasi sosial dan dialog peradaban. Distingsi paling penting antarmanusia bukan ideologi, politik atau ekonomi, akan tetapi kebudayaan manusia berusaha menjawab secara fundamental, siapakah manusia? Hal ini terjawab secara tradisional dengan rujukan pada hal yang paling bermakna bagi mereka antara lain: geneologis atau silsilah, agama, bahasa, sejarah, nilai-nilai tradisi dan institusi. Di samping itu manusia juga mengidentifikasi diri dengan kelompok budaya etnik, komunitas agama, dan yang paling luas adalah peradaban (civilization).

Huntington (1996) mendefinisikan peradaban (civilization) sebagai ruang, kawasan budaya (culture area), sebuah koleksi dari aneka karakteristik dan fenomena budaya yang mencakup nilai, norma, institusi, dan pola pikir dari anggota masyarakat dari generasi ke generasi yang diterima paling penting dan utama. Untuk memperkuat pernyataan tersebut di atas, bahwa peradaban yang akan tampil sebagai penglima keberadaan manusia yaitu pemikiran kelompok konservatif dari semua agama konservatif yang paling bertahan, karena kelompok konservatif maupun moderat suatu agama yang menghargai budaya. Baik budaya lokal yang dikuatkan oleh kearifan lokalnya maupun budaya nasional dan global. Pandangan serupa dikemukan Wajidi (2014) yang mengungkapkan bahwa dialektika (interaksi) antara agama dan budaya dapat saling mempengaruhi karena pada keduanya terdapat nilai dan simbol yang dituangkan dalam bentuk upacara.

Kearifan tidak hanya berupa norma-norma dan nilai-nilai budaya, melainkan juga segala unsur gagasan, termasuk yang berimplikasi pada teknologi, penanganan kesehatan dan estetika. Dengan demikian, kearifan lokal itu lebih dititikberatkan sebagai kemampuan suatu wilayah dalam menyerap serta mengadakan seleksi dan pengelolaan secara aktif terhadap pengaruh kebudayaan luar atau asing, sehingga tercapai bentuk ciptaan baru yang tidak terdapat di wilayah lain. Menurut Ahimsa Putra 
dalam Marjanto (2015) mendefinisikan kearifan lokal sebagai perangkat pengetahuan pada suatu komunitas, baik yang berasal dari generasi ke generasi sebelumnya maupun dari pengalamannya berhubungan dengan lingkungan dan masyarakat lainnya, untuk menyelesaikan secara baik dan benar berbagai persoalan dan/atau kesulitan yang dihadapi. Konsep ini diterapkan dalam upacara ruwatan dan pemotongan rambut gimbal di lingkungan alam dan lingkungan sosial Dieng. Keraf dalam Fatmawati (2014) menyebutkan bahwa kearifan lokal merupakan semua bentuk pengetahuan, keyakinan, pemahaman (wawasan), serta adat kebiasaan atau etika yang menuntun perilaku manusia dalam kehidupan komunitas ekologi. Konsep ini diterapkan dalam rangka mengkonservasi benda-benda situs seperti logam, perak, perunggu dan besi dengan menggunakan buah lerak. Kearifan lokal merupakan kearifan lingkungan dalam bentuk tata nilai atau perilaku hidup dalam masyarakat di suatu tempat atau daerah, baik antarsesama masyarakat maupun dalam berinteraksi dengan lingkungan mereka. Kearifan lokal tidak sama pada tempat, waktu, dan suku bangsa. Perbedaan ini disebabkan oleh tantangan alam dan kebutuhan hidup yang berbeda-beda sesuai dengan lingkungan alam dan sosialnya (Situmorang \& Simanjuntak, 2015).

Secara garis besar "kearifan lokal" dapat diartikan sebagai kearifan dalam kebudayaan tradisional, dengan catatan bahwa yang dimaksud dalam hal ini adalah kebudayaan tradisional suku-suku bangsa. Inti dari kearifan lokal merupakan kebijakan para leluhur masyarakat Desa Mbawa yang telah disepakati dan sudah teruji secara empiris dari pengalaman secara turun-temurun. Tujuan dari semua itu adalah untuk mewujudkan kesejahteraan dan keharmonisan secara lahir dan batin yang diwujudkan melalui upacara tradisional Raju yang mencerminkan toleransi antarumat beragama yang ada di Desa Mbawa. Toleransi antarumat beragama tidak hanya dicerminkan melalui upacara Raju, tetapi juga melalui Uma Leme sebagai wadah penyatuan antarumat yang berbeda agama. Penelitian yang dilakukan oleh Satyananda (2015) mengenai Uma Leme, hanya sebatas pada fungsi Uma Leme sebagai tempat tinggal dan interaksi sosial antarpenghuninya. Uma Leme dalam penelitian ini memiliki fungsi sebagai wadah toleransi.

Nilai budaya tidak semua bersifat kemajuan, dibutuhkan sikap kritis dan selektif untuk meninggalkan budaya tradisional (yang statis) seperti model mental yang menghambat pembangunan. Oleh karena itu, perlu mengembangkan model revolusi mental, restorasi sosial yang bersifat progresif dan kompetitif yang antara lain dicirikan oleh orientasi ke depan, kerja keras dan kreatif, hemat untuk investasi, pendidikan sebagai kunci, menjujung tinggi prinsip pemanfataan, saling percaya lintas batas keluarga, agama beretika dan adil serta otoritas yang meneyebar (Tule, 2010).

\section{METODE}

Berdasarkan rumusan masalah yang telah dipaparkan serta tujuan yang ingin dicapai maka penelitian ini menggunakan metode observasi, wawancara serta studi pustaka. Secara umum, pengertian observasi adalah cara menghimpun bahan-bahan keterangan (data) yang dilakukan dengan mengadakan pengamatan dan pencatatan secara sistematis terhadap fenomenafenomena yang sedang dijadikan sasaran pengamatan (Sudjiono, 2009). Observasi dilakukan dengan cara mengamati secara langsung di lapangan mengenai segala hal fenomena yang berkaitan dengan tema penelitian. Seperti misalnya pola hubungan sosial antara masyarakat Donggo (baik pola hubungan formal maupun nonformal), uma leme, tempat ibadah (gereja katholik, protestan maupun masjid) dan lain sebagainya.

Wawancara merupakan proses memperoleh keterangan untuk tujuan penelitian dengan cara tanya jawab dengan menggunakan alat yang dinamakan interview guide. Metode wawancara digunakan sebagai metode untuk mengumpulkan data primer yang langsung diperoleh dari 
informan. Pemilihan informan dalam penelitian ini dilakukan dengan cara purposive yaitu pengambilan informan yang disesuaikan dengan tujuan penelitian, sehingga informan yang dipilih dalam penelitian ini adalah mereka yang betulbetul menguasai persoalan-persoalan yang diteliti. Wawancara dilakukan dengan beberapa informan diantaranya Yosef Ome dan Jamaluddin (juru pelihara situs uma leme), H. Gani Maskur (mantan Ketua Umum Majelis Ulama Bima) dan Heru Kapu (tokoh orang Katholik), tokoh orang Protestan.

Selain observasi dan wawancara, penelitian ini juga dilengkapi oleh studi pustaka untuk mendukung hasil pengumpulan data di lapangan. Studi pustaka ini dilakukan sebelum dan sesudah turun lapangan. Adapun tujuan dari studi pustaka ini adalah untuk memperkuat data dan analisis tentang kearifan lokal masyarakat Desa Mbawa, Kecamatan Donggo, Kabupaten Bima, Nusa Tenggara Barat dalam mewujudkan toleransi beragama.

Analisis data dilakukan dengan cara deskriptif kualitatif, yakni memberikan gambaran yang lengkap tentang segala unsur yang mencerminkan adanya kearifan lokal di Desa Mbawa yang digunakan sebagai sarana untuk mewujudkan toleransi beragama. Unsur-unsur tersebut dapat tercermin melalui pemberian nama, upacara raju, keberadaan uma leme dan lain sebagainya. Prosesnya dilakukan melalui pemilihan data, reduksi data, dan langkah terakhir adalah mendeskripsikan sesuai dengan pokok bahasan yang menjadi tujuan dari penelitian ini.

\section{HASIL DAN PEMBAHASAN}

\section{Identifikasi Masyarakat Mbawa}

Nama etnis yang mendiami Desa Mbawa yaitu etnis Donggo. Dilihat dari persebaran etnis Donggo meliputi sebagian wilayah Kabupaten Dompu dan Kabupaten Bima. Wilayah asal etnis Donggo adalah Kecamatan Donggo, Kabupaten Bima dan empat Kecamatan yang berada di Kabupaten Dompu yaitu, Kecamatan Huu, Dompu, Kempo dan Kelo. Etnis Donggo adalah kelompok etnik, namun tidak memiliki bahasa sebagai identitas otonom. Etnis Donggo menggunakan Bahasa Mbojo, sebagaimana salah satu etnis yang menempati Kabupaten Bima.

Etnis Donggo menganggap dirinya berasal dari daerah Swangga, suatu tempat yang terletak di suatu pegunungan yang tinggi dan terpencil. Mereka hidup dalam kelompokkelompok kecil dan setiap kelompok dipimpin oleh pimpinan yang disebut Naka-Niki. Kelompokkelompok kecil tersebut sering terjadi perang atau konflik. Etnis Donggo mengembangkan pola hidup bersifat nomaden dan hidup dari berburu. Jaman itu mereka sebut Naka-Niki. Etnis Donggo juga menyebut jaman itu sebagai jaman 'terbang' (ngemo), karena waktu itu orang yang meninggal tidak dikubur, tetapi terbang dan menghilang begitu saja.

Etnis Donggo tidak lagi hidup di pegunungan dengan kehidupan yang keras. Etnis Donggo mulai turun ke dataran rendah. Di dataran rendah etnis Donggo secara berangsur-angsur berkomunikasi dengan kelompok lain, diantaranya dengan yang datang dari luar. Perubahan yang terjadi antara lain semakin berkurangnya konflik antarkelompok. Selain berburu mereka mulai menetap dan bercocok tanam. Mulai saat itu terbentuk kelompokkelompok semacam klen (rafu), masuknya unsur-unsur agama Hindu dengan menghormati alam semesta, karena alam semesta pengejawantahan secara kasat mata simbol Tuhan, manusia harus selaras dengan alam.

Kelompok-kelompok sosial menjadi semakin besar dan adat istiadat semakin berkembang. Pimpinan kelompok yang sudah menjadi lebih besar itu disebut Neuhi. Sekitar abad ke-14 kedudukan dan peran Neuhi itu sudah amat kuat, sehingga kekuatan itupun telah diwujudkan dalam bentuk rumah Uma Leme, sebagai simbol penyatuan etnik Donggo yang ada di Desa Mbawa.

Pengaruh agama Khatolik, Protestan, dan Islam baru masuk pada abad ke-20. Dengan masuknya ketiga ajaran agama itu masyarakat Donggo mulai terbuka dengan dunia dan 
masyarakat luar. Etnis Donggo dengan cepat menerima pembaharuan-pembaharuan. Keadaan alam yang bergunung-gunung dan ganas menyebabkan etnis Donggo turun ke daerah yang lebih rendah di sekitar daerah Donggo sekarang. Etnis Donggo bertemu dan bercampur dengan kelompok lain yang datang dari luar, misalnya dari Flores, Ambon dan lain-lain. Dengan adanya pengetahuan dari orang luar, barulah etnis Donggo menetap dan membuat rumah.

Masyarakat Desa Mbawa pada hakikatnya sangat membanggakan hidup harmonis antara pemeluk agama Islam, Kristen Protestan, dan Khatolik. Sementara itu, tidak ada hal-hal yang mengusik ataupun mengganggu kerukunan tersebut, masing-masing saling menjaga dan menghormati. Etnik Donggo yang berada di Desa Mbawa tidak memandang mayoritas dan minoritas. Walaupun dari jumlah penduduk Desa Mbawa pada saat ini 4.774 jiwa yang terdiri dari pemeluk Islam 3.737 jiwa, Protestan 96, dan Khatolik 941 jiwa (Data Statistik Desa Mbawa, 2015). Tempat beribadah dari masingmasing agama seperti Masjid Jaba Nur, Gereja Khatolik St. Paulus Mbawa serta gereja Protestan dengan nama GKII (Kemah Injil).

Walaupun letak ketiga tempat ibadah ini saling berjauhan, namun menurut pengakuan informan ketika ada perayaan hari besar agama yang diselenggarakan di masing-masing tempat ibadah, para pemuda dari masing-masing agama saling mengundang satu sama lain.

Mata pencaharian masyarakat Mbawa sebagai petani ladang dengan sistem tebas bakar (ngoho), pohon yang sudah ditebang lalu dibakar. Sisa dari bakaran yang disebut dengan boro kemudian dibersihkan. Sebelum memulai bercocok tanam, diselenggarakan upacara Raju untuk menentukan hari yang tepat mulai menanam padi, jagung dan lain-lain. Setelah itu, lahan siap untuk ditanami sambil menanti hujan. Setelah tanaman cukup besar, untuk menghindari hama diadakan upacara mengusir hama yang disebut dengan upacara Kadaki.
Kegiatan berburu sudah berakar lama dalam masyarakat Mbawa. Berburu dilaksanakan dalam kelompok yang dilakukan seminggu atau sebulan sekali. Masyarakat Desa Mbawa juga melakukan perburuan massal setahun sekali. Pembagian hasil buruan tergantung banyak sedikitnya tenaga dan jasa yang diberikan oleh seseorang. Namun kalau hasil buruannya cukup banyak, daging buruannya diberikan secara cuma-cuma kepada penduduk kampung. Masyarakat Desa Mbawa menafsirkan hasil binatang buruan pada hasil pertanian. Apabila masyarakat Mbawa banyak memperoleh kijang (Maju) maka hasil pertanian akan berkurang, sedangkan kalau mereka banyak memperoleh babi hutan (Wawi) maka mereka tafsirkan hasil pertanian akan melimpah, walaupun binatang babi hutan (Wawi) paling rakus merusak tanaman penduduk. Hal ini menandakan alam di sekitar Desa Mbawa subur. Ternak yang dipelihara sapi, kuda, kambing, kerbau, ayam dan babi. Ukuran kekayaan pada masyarakat etnik Donggo adalah luasnya sawah, ladang dan banyaknya ternak.

\section{Toleransi Kehidupan Beragama Melalui Kearifan Lokal Pemberian Nama}

Jika ingin menulusuri seseorang, salah satunya melalui identitas yang mudah dikenal, dari mana yang bersangkutan berasal dan agama apa yang dianut dan diyakininya. Untuk daerah asal tentu sangat berkaitan dengan etnik seperti sistem penamaan, sistem kekerabatan, sistem pelapisan sosial, stratifikasi sosial (marga, fam dan soroh). Sedangkan dari keyakinan yang dianut dapat dilihat dari pemberian nama saat pembaptisan dan kelahiran. Pada masyarakat Mbawa pemberian nama dari dua bahkan tiga agama sebagai kayakinannya sudah tidak asing lagi. Padahal agama yang dianut dan diyakininya hanya satu agama. Namun untuk penghormatan karena agama itu adalah ciptaan Tuhan maka seorang warga sangat banyak mengutip dan mencontoh tokoh-tokoh maupun nabi-nabi dari dua agama yang berbeda. Strategi seperti ini belum tentu dapat diterapkan pada etnik 


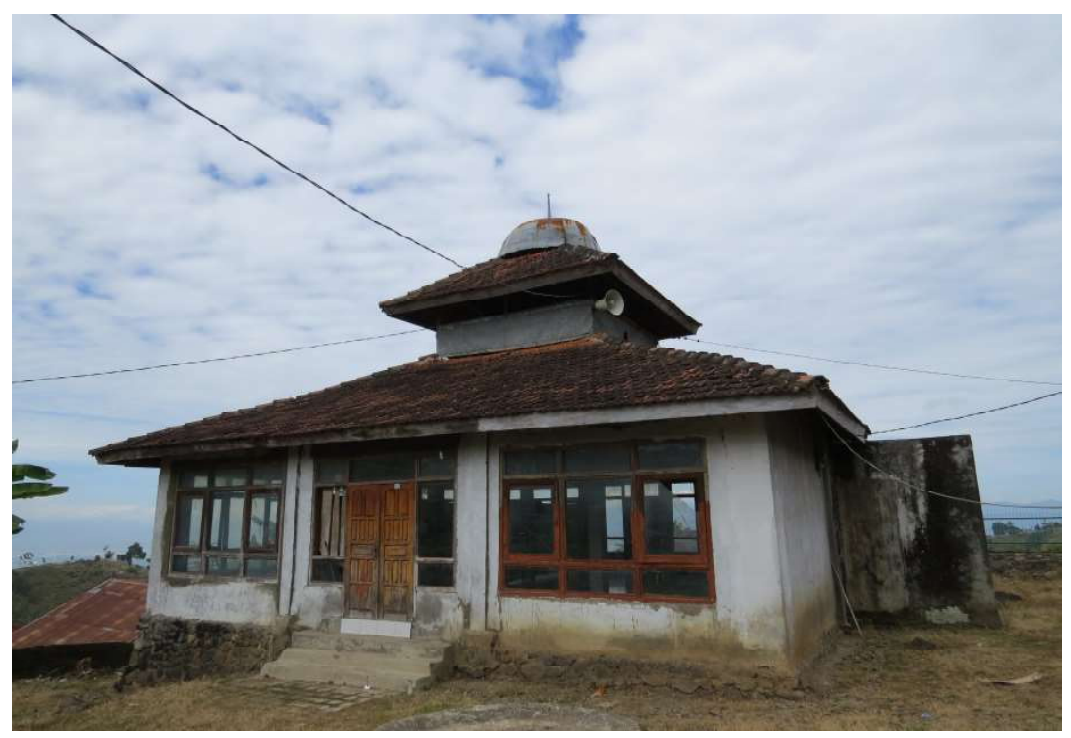

Gambar 1 Masjid Jabal Nur Mbawa

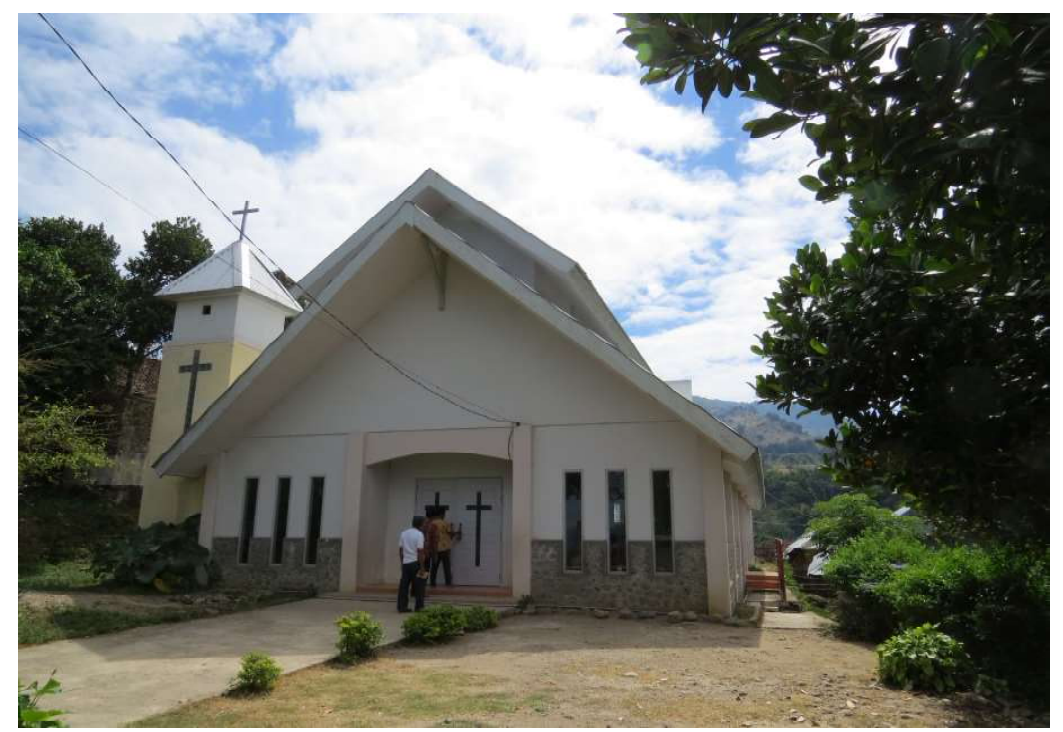

Gambar 2 Gereja Khatolik St. Paulus Mbawa

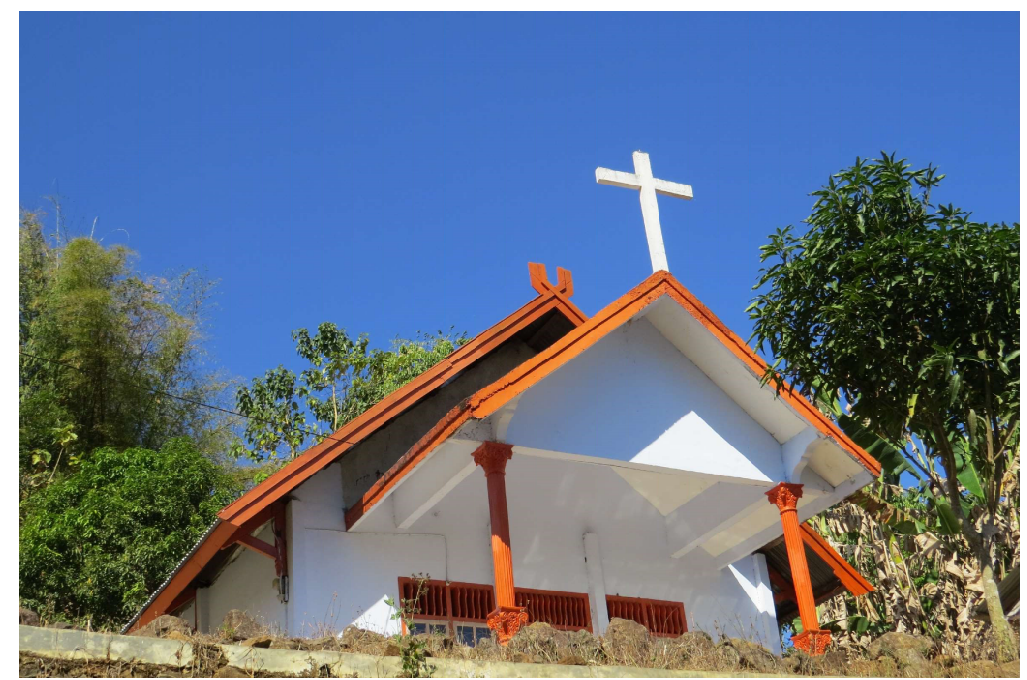

Gambar 3 Gereja Protestan GKII (Kemah Injil) 
maupun daerah lain untuk mewujudkan toleransi beragama. Namun bagi etnik Donggo yang berada di Desa Mbawa akan merasa aman, bermoral dan sudah terbukti hasilnya dalam kehidupan bermasyarakat.

Nama-nama anggota masyarakat Mbawa yang menggunakan dua agama seperti nama Yohanes Ibrahim, Anderias Ahmad, Bernadus Abu Bakar Wrg Prote, Petrus Herman Fabianus Tabi, Ignatius Ismail, Matinus Tamrin, Markus Jafar dan lain-lain. Untuk kaum perempuan akan memakai nama seperti Kristin Siti Hawa, Marta Maemunah, Marta Hadijah, Anastasia Nuraini dan lain-lain. Pada umumnya nama-nama tersebut digunakan oleh pemeluk agama Khatolik dan Protestan sebagai bentuk pengejawantahan terhadap sikap toleransi.

Untuk penyebutan istilah secara tradisi kekerabatan masih dipegang teguh, seperti menyebut ama untuk ayah, Ina untuk ibu, Wi untuk istri, Rahi untuk suami, ulu untuk anak sulung, Cumpukai untuk anak bungsu. Penyebutan keluarga luas pada etnik Donggo Ngge'e La'bo yang terdiri dari keluarga inti, ditambah dengan nenek, bibi, atau kemenakan. Anggota keluarga dari keluarga inti maupun dari keluarga luas belum tentu menganut satu agama dan keyakinan. Pada awalnya etnik Donggo merupakan sasaran utama untuk penyebaran agama Katolik dan Protestan. Menurut pandangan agama Islam, Katolik serta Protestan, etnik Donggo tahun 1516 masih dianggap kafir dengan sistem kepercayaan Makakimbi. Sementara itu di kota Bima sedang terjadi pengembangan agama Islam yang sangat pesat. Sesuai dengan perintah Sultan Muhammad Salahuddin, agar tidak terjadi persaingan untuk mendapatkan umat maka orang-orang Portugis yang ada di Bima diarahkan ke etnik Donggo seperti Desa Mangge dalam penyebaran agama yang dianutnya. Kemudian di Donggo dibangun sekolah Khatolik yang mendatangkan guru-guru agama dari pulau Flores seperti guru Dambo.

\section{Upacara Raju}

Raju merupakan upacara pembasmian hama dan penentuan musim tanam. Upacara ini dilaksanakan setiap tahun sebelum musim tanam. Untuk penentuan waktu ditentukan oleh bulan (Wura). Ada tiga jenis upacara Raju, pertama Raju Na'e dilaksanakan selama tujuh hari. Kedua, Raju to'i dilaksakan selama lima hari. Raju to'i Poda dilaksanakan selama tiga hari.

Maksud dan tujuan penyelenggaraan upacara Raju yaitu mengusir hama dan penyakit tanaman. Jika hama dan penyakit sudah diusir maka harapan petani untuk mendapatkan hasil panen lebih yakin. Makin banyak mendapat tangkapan hama seperti ulat dan tikus pada saat penyelenggaran Raju maka, semakin meyakinkan untuk mendapatkan hasil panen yang lebih banyak.

Proses penyelenggaraan Raju dapat diurut sebagai berikut: 1) Masyarakat Desa Mbawa dari tiga pemeluk agama berkumpul di rumah tradisional Uma Leme. Anggota masyarakat Mbawa yang hadir di Uma Leme tidak ada pengelompokan berdasarkan agama maupun keyakinan; 2) Seluruh anggota masyarakat hadir berdoa melalui sarana sesaji Toho ro dore yaitu berupa karado beras yang ditumbuk halus yang dicampur dengan parutan kelapa dan garam serta dilengkapi dengan pisang dan sirih pinang. Harapan dari doa yang dilakukan agar upacara Raju lancar dan sukses; 3) Melakukan perburuan di Gunung Iku (Lao nggalo di Doro Iku) menuju ke bawah (Lao Awa) dengan maksud membuang segala penyakit tanaman melalui aliran air dari hulu ke hilir, karena aliran air sering membawa penyakit sehingga pengembaliannya juga harus lewat aliran air. Sesaji yang dibawa pada saat perburuan ini adalah sesaji yang telah didoakan di Uma Leme; 4) Setelah Lao Awa, dilanjutkan Lao Ese (menuju ke atas). Perjalanan menuju ke atas ini dimaksudkan membuang hama berupa ulat, ular, dan lain-lain. Ulat, ular dan lain-lain dipercaya oleh para petani datangnya dari atas sehingga pengembaliannya juga ke arah atas; 5) Proses selanjutnya menuju Lao ta da (utara) untuk membuang belalang (Kasanto ro komoa). 
Binatang seperti belalang dipercaya datangnya dari utara, sehingga harus dikembalikan ke arah utara; 6) Selanjutnya, menuju Lao ta do (selatan) untuk membuang hama tikus ke arah laut. Binatang tikus dipercaya oleh para petani etnik Donggo datangnya dari arah selatan, sehingga pengembaliannya ke arah laut.

Terakhir menuju Sondosia, untuk membuang semuanya ke arah laut agar lebur dengan air laut. Jika hama sudah dibuang ke laut harapan masyarakat Desa Mbawa agar hama tidak kembali mengganggu dan merusak tanaman. Pada saat membuang hama dan penyakit tanaman sesaji dilengkapi seekor ayam dan sebelum membuang semua hama ditempatkan pada tempat yang khusus sebagai rasa penghormatan.

Upacara Raju merupakan salah satu kearifan lokal sebagai wahana pendidikan untuk belajar kebudayaan etnik Donggo. Dalam upacara Raju anggota etnik Donggo akan mengenal dirinya sendiri maupun karakter lokalnya, bukan agama sebagai sumber rujukannya. Pandangan seperti ini selalu menjadi tema pasca-reformasi. Di Indonesia, konsep mengenai kearifan lokal menjadi tema yang kerap kali disinggung sebagai jawaban atas berbagai persoalan yang timbul dari proses pembangunan, modernisasi maupun globalisasi yang datang "dari luar". Khasanah lokal dan tradisional kembali dilirik dan dianggap sebagai obat mujarab untuk berbagai persoalan. Termasuk persoalan integrasi toleransi antarpemeluk agama yang berbeda. Umat Muslim di Desa Mbawa sudah merasa cukup kemuslimannya, demikian pula umat Katolik dan Protestan sudah merasa cukup ke-Katolikan dan keProtestanannya. Sikap nyata yang bisa diwariskan sebagi simbol penyatuan dan toleransi, telah diwujudkan dalam bentuk rumah tradisional, Uma Leme dengan penyelenggaraan upacara tradisional Raju. Upacara Raju telah mengandung nilai-nilai budaya yang sejalan dengan nilai-nilai agama yang dianut oleh etnik Donggo, seperti percaya dengan adanya kekuatan Ilahi yang tidak dimiliki oleh manusia, menjalin hubungan harmonis antarmanusia, dan selalu harus menjaga keharmonisan antara manusia dengan lingkungannya.

Toleransi serupa juga diperkuat pada tulisan Armini (2013) mengenai keanggotaan organisasi Subak di beberapa daerah di Bali, yaitu di Desa Sinduwati, Desa Angantiga, dan Desa Ekasari, yang di dalamnya terdapat berbagai macam etnik dan agama. Dalam penelitian tersebut organisasi Subak dapat dijadikan sebagai wadah toleransi multietnis dan multiagama. Meskipun ada kecenderungan hegemoni dari pihak mayoritas untuk menerapkan awig-awig (peraturan subak) dalam kerangka masyarakat Bali dan agama Hindu. Menurut pandangan anggota Subak yang beragama Hindu, pelaksanaan upacara di Pura Subak adalah kewajiban semua anggota yang beragama Hindu. Pandangan yang demikian mengharuskan semua anggota (khususnya yang beragama Hindu) terlibat dalam pelaksanaan upacara ritual. Padahal dalam beberapa kasus tidak semua anggota Subak beragama Hindu dan tidak semua anggota dapat melakukan upacara Hindu di Pura Subak. Untuk mewujudkan toleransi, anggota Subak non-Hindu selaku anggota minoritas secara sukarela menyumbang sejumlah dana tanpa ikut terlibat dalam pelaksanaan upacara tersebut.

Kasus seperti di atas mengenai toleransi antaretnik dan antaragama telah ditemukan pula oleh Sudarma (2001) dengan kasus penelitian di Desa Medewi, Kecamatan Pekutatan, Kabupaten Jembrana. Pada saat upacara magpag toya (jemput air) baik umat Islam maupun Hindu bersama-sama melakukan upacara pada tempat yang berbeda. Anggota yang beragama Hindu menggelar upacara di Pura Bedugul (Pura Subak) sedangkan anggota yang beragama Islam melakukan selamatan dan berdoa di mushola yang letaknya tidak jauh dari Pura Subak. Purna (2001) juga menemukan hal yang sama di Desa Pegayaman, Kecamatan Sukasada, Kabupaten Buleleng. Dalam pelaksanaan upacara ngusaba dilaksanakan sepenuhnya oleh masyarakat Hindu di Pura Subak sedangkan umat Islam melakukan 
selamatan di masjid dengan membaca beberapa salawat dan doa-doa dalam kitab maulid.

\section{Fungsi Uma Leme}

Rumah adat Uma Leme sebagai wadah pemersatu dan mengandung kekayaan baik material maupun nonmaterial pada masyarakat Desa Mbawa. Secara fisik Uma Leme ini sudah disahkan oleh pemerintah Kabupaten Bima sebagai bangunan cagar budaya.

Berdasarkan aturan adat Rafu Winta dan Rafu Guli, ketua adat harus dari agama nonIslam karena setiap penyelenggaraan upacara adat di Uma Leme makanan utamanya sebagai pelengkap sesaji adalah dari daging babi. Sementara ini, masyarakat muslim menerima daging babi sebagai daging persembahan. Pada saat penelitian sudah ada beberapa tokoh dari umat Khatolik memiliki pemikiran agar toleransi beragama tetap harmonis seperti sekarang, ada keinginan mengganti daging babi menjadi daging lain yang bersifat lebih netral, misalnya daging kerbau, ayam maupun sapi. Kekhawatiran ini muncul jika generasi yang akan datang memiliki interpretasi berbeda tentang pelengkap sesaji dengan generasi sekarang.

Upacara Raju yang diselenggarakan di Uma Leme tahun 2015 diketuai oleh Yoseph Ome dari tokoh agama Khatolik, untuk kerukunan umat beragama di desa Mbawa dipercaya untuk mengakomodir aspirasi umat Khatolik di wilayahnya. Masalah tidak pernah ada ketika berdampingan dengan umat Islam dan Protestan, selama budaya musyawarah dan gotong royong yang dipakai sebagai acuan. "Kami satu rumpun dan keluarga yang sama, hanya keyakinan saja yang berbeda!" demikian ungkapnya. Bila ada pernikahan ataupun kerja sosial lainnya yang antusias membantunya dan lebih berperan dalam menyelesaikan pekerjaan justru umat yang berbeda agama dari penyelenggara acara. Demikian pula umat Islam dan Protestan tidak merasa canggung ketika berdampingan dengan pemeluk agama Khatolik.

Keunikan yang sangat menarik juga didapatkan di Desa Mbawa, dalam satu rumah - dalam keluarga inti (nuclear family), terdapat perbedaan agama dan keyakinan. Bila seorang ayah beragama Khatolik, anak, saudara maupun istri terdapat keyakinan yang berbeda seperti Islam maupun Protestan. Dalam rumah tidak ada pertentangan ataupun kesenjangan antara anak dan orang tua apalagi istri. Anggota keluarga tetap saling menghormati dan menghargai sesuai dengan apa yang dipeluk dan diyakini. Ketika ada urusan keluarga, mereka tetap hadir dan berkumpul. Emosi keagamaan dan keyakinan serta emosi keluarga selalu dibedakan posisinya

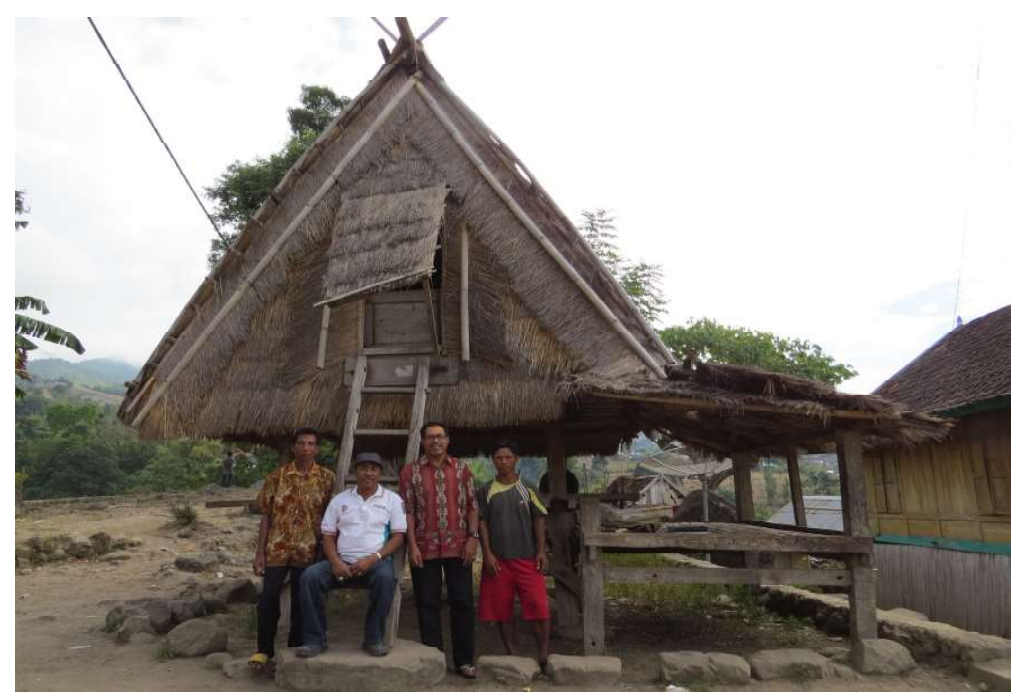

Gambar 5 Uma Leme sebagai wadah penyatuan antarumat 


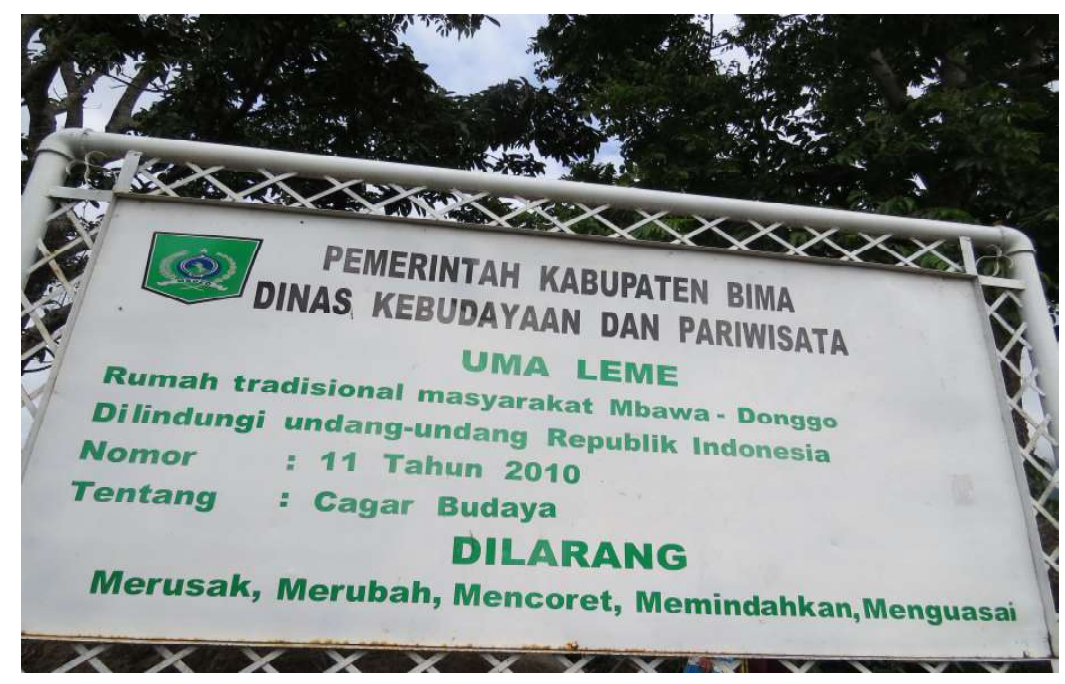

Gambar 4 Bukti pengesahan Uma Leme sebagai Cagar Budaya

karena kedua emosi itu mengajarkan kedamaian dan keharmonisan antarumat manusia. Namun sebaliknya, kedua emosi ini sangat mudah juga diprovokasi untuk membangkitkan sentimen kelompok. Para tokoh agama menyikapi secara arif yaitu dengan cara mengedepankan rasionalitas daripada emosional dalam menyelesaikan suatu masalah.

Beberapa pemuka agama Islam mengatakan, walaupun penduduk Desa Mbawa mayoritas beragama Islam, namun tetap menghargai umat Khatolik maupun Protestan, karena mereka adalah penduduk asli berarti saudara juga. Sikap toleran juga dapat dibuktikan pada saat perayaan hari raya dari ketiga umat beragama berbeda tersebut. Setiap perwakilan selalu diundang untuk menghadiri acaranya. Jika ada acara perayaan Idul Fitri umat Islam tetap silaturahmi ke tempat umat lain seperti umat Khatolik maupun Protestan untuk mohon maaf lahir dan batin. Pada saat bulan Ramadhan tiba waktu umat Islam melaksanakan puasa, pemeluk agama lain juga ikut melaksanakan aktivitas layaknya seperti umat Islam. Bahkan umat Khatolik dan Protestan tidak memasak maupun melakukan aktivitas yang bisa mengganggu maupun membatalkan puasa bagi umat Islam. Untuk membuktikan hal ini, peneliti hadir langsung ke Desa Mbawa ketika bulan puasa tahun $1436 \mathrm{H}$. Peneliti menemui keluarga muslim dan keluarga Khatolik. Kalau di keluarga muslim sudah pasti tidak akan menyuguhkan minuman pada saat bulan puasa. Sedangkan di keluarga Khatolik juga tidak menyediakan makanan dan minuman meskipun mereka sedang tidak berpuasa. Dari hal inilah dapat dilihat toleransi yang tinggi umat Khatolik terhadap umat Islam.

Sikap toleran seperti di atas diawali pada tahun 1925 di Kota Bima pada saat pemerintahaan Kesultanan Bima membangun masjid Raya Raba Baitul Hamid. Bersamaan itu pula Sri sultan mengijinkan dan mewakafkan tanah Sri Sultan untuk membangun gereja Protestan. Walaupun jumlah Umat Protestan pada saat itu hanya 6 orang seperti Tuan Kalase (Kepala HIS), Tuan Meru Soloksiner (penili), Tuan Saba dari Timor Timur yang juga jadi mantri kesehatan serta Tuan Seli (Mantri hewan). Tanggal 13 Desember 1633 di Bima sudah ada misi Khatolik dari orang-orang Portugis. Sri Sultan mengijinkan kehadiran pastur dari Jerman mengajarkan Bahasa Inggris dan untuk menyebarkan agama Khatolik yang dipusatkan di Desa Mbawa-di daerah Donggo yang pada waktu itu masyarakatnya masih menganut kepercayaan Makakimbi-Makakamba (Animisme dan Dinamisme).

Kerukunan yang terjadi antarumat dalam satu rumah dapat digambarkan dalam diagram penyatuan dalam rumah adat (Uma Leme). 
Peran Tokoh Agama, Masyarakat dan Para Orang Tua Dalam Perbedaan

Masyarakat Desa Mbawa sangat menghargai dan menghormati tokoh agama maupun tokoh masyarakat. Masyarakat tidak akan bertindak dan berbuat sendiri-sendiri, bila dilarang oleh tokohnya pasti akan diikuti oleh anggota masyarakatnya. Tokoh tua lebih proaktif memberikan solusi ketika ada permasalahan. Walaupun selama ini Etnik Donggo sudah mengenal dunia gaib dalam istilah setempat disebut dengan Rafu, lengkapnya Parafu Ro Pamboro. Parafu merupakan roh atau sesuatu yang dianggap gaib. Jaman terdahulu ketika ada masalah masyarakat selalu minta tolong pemecahan masalahnya kepada Rafu.

Untuk mentradisikan Rafu sampai saat ini masyarakat Donggo di Desa Mbawa masih mencatat ada keturunan Rafu yaitu: Rafu Winte, Rafu Guli, Rafu Ni'u, Rafu Kasa'a, Rafu Latu, Rafu Rato, Rafu Sado dan Rafu Rae. Para generasi muda sampai sekarang dikenalkan dan diajarkan tentang Rafu dan unsur-unsur pembeda dari kearifan lokal maupun agama dan keyakinan yang dianut oleh masyarakat Desa Mbawa. Para tokoh agama dan masyarakat harus mengenalkan dan mengajarkan tentang perbedaan, pendidikan multikultur, dan multiagama dalam masyarakat. Sekalipun dalam keluarga yang hidup seiman, mengenai perbedaan agama dan kebudayaan perlu diajarkan dan dijelaskan pada anak-anak sedini mungkin. Terlebih lagi, pada anak-anak yang rasa ingin tahu dan penalarannya sudah mulai tumbuh, penjelasan diberikan dengan bahasa yang mudah dimengerti. Orang tua perlu menjelaskan agama apa yang anak pilih serta mengarahkan agar alasan dalam pemilihan agama tersebut lebih dititikberatkan pada agama yang terbaik menurut anak. Anak juga harus mengenal dan memahami kebudayaan orang tua dari etnik mana anak berasal. Selanjutnya anak-anak juga harus dikenalkan etnik yang ada di lingkungan sosialnya.

\section{Wujud Nyata Toleransi}

Bertitik tolak dari uraian di atas bahwa fungsi uma leme menjadi amat penting. Uma leme sebagai pusat toleransi dan sumber penyatuan antarumat beragama. Uma leme sebagai pusat orientasi penyelenggaraan upacara Raju. Uma Leme dan upacara Raju dapat dijadikan rujukan kesadaran sosial antarumat yang berbeda agama.

Dalam antropologi sosial uma leme bagi orang Donggo yang ada di Desa Mbawa merupakan suatu kekuatan budaya yang berperan sentripetal (memusat) dalam menyatukan para warga Desa Mbawa secara lintas agama, lintas golongan ke dalam suatu unit

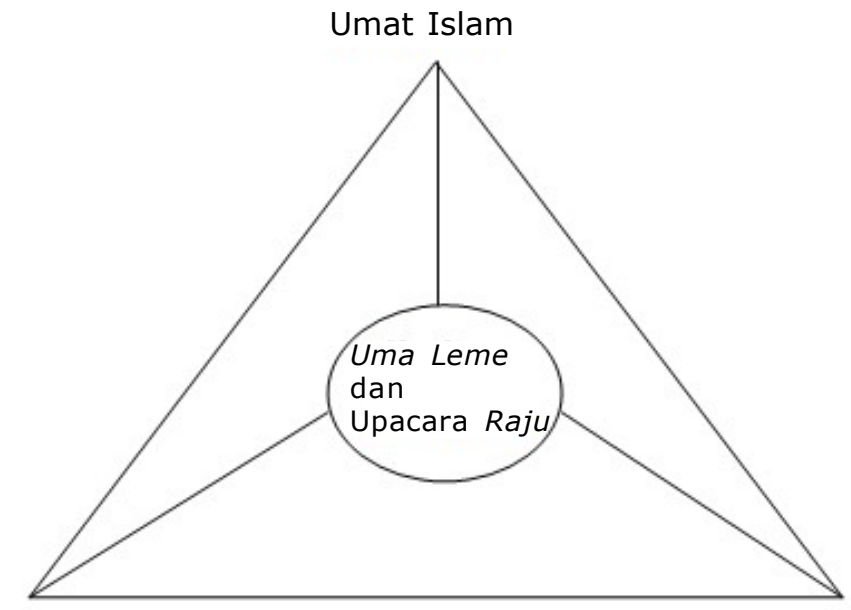

Umat Khatolik

Umat Protestan

Diagram Penyatuan dalam Rumah Adat (Uma Leme) 
sosial dari keluarga inti, rumpun-rumpun keumatan sampai wilayah Desa Mbawa. Konsekuensi dari pernyataan yang diwadahi uma leme telah terejawantahkan ke dalam sistem pemberian nama yang bersumber dari tokohtokoh agama yang ada baik Islam, Khatolik maupun Protestan. Sistem pemberian nama ini menandakan ada sikap toleran dan harapan untuk keberhasilan terhadap orang yang sudah pernah berprestasi dalam pencapaian nilai moral, budi pekerti, dan penguatan jati diri. Di samping itu merujuk pada tokoh-tokoh agama baik Islam, Khatolik, maupun Protestan yang terdapat di Desa Mbawa, pemberian nama juga merupakan sebuah doa untuk keberhasilan.

\section{Pengenalan Budaya Lokal Dalam Keutuhan NKRI}

Masyarakat Indonesia sangat bangga dengan keragamannya, terutama terhadap keragaman etnik, budaya, dan agama. Keragaman etnik, budaya, dan agama adalah aspek yang sangat strategis dan paling efektif dalam membina kehidupan masyarakat yang rukun dan damai, harmonis, maju dan sejahtera di Negara Kesatuan Republik Indonesia (NKRI). Oleh karena itu, tidak mengherankan penelitian para pakar budaya (antropologi) serta pengembang budaya lokal menjadi lembaga yang strategis dan paling efektif dalam membina dan mempopulerkan mengenai hidup rukun, damai, toleran, harmonis, maju, dan sejahtera.

Sudah ada pakar budaya maupun instansi yang telah meneliti dan mempublikasikan kebudayaan lokal yang menekankan hubungan antaretnik maupun hubungan antaragama dalam mewujudkan toleransi dan keharmonisan, antara lain sebagai berikut. Pertama, disinyalir bahwa budaya kekerabatan yang dibangun dan dihayati di atas tanah suku (tanah ulayat), monumenmonumen budaya, dan rumah adat merupakan nilai budaya lokal. Hal tersebut mampu mempersatukan penganut agama dalam suatu masyarakat Keo yang majemuk menjadi suatu masyarakat yang toleran dan harmonis, yang tentu merupakan situasi dan kondisi yang kondusif demi pembangunan menuju kemajuan dan kesejahteraan (Tule, 2010).

Kedua, Dhana, dkk. telah menulis integrasi antaretnik Bali dan Sasak melalui upacara Perang Topat di Pura Taman Lingsar Lombok Barat. Hasil penelitian ini menggambarkan bahwa orang Sasak yang kini beragama Islam dan orang Bali yang beragama Hindu ternyata dapat melakukan upacara Perang Topat secara bersamaan terpusat di Pura Taman Lingsar. Faktor tersebut disebabkan karena ada kesamaan atau kemiripan unsur budaya dari kedua kelompok etnik tersebut (Dhana, dkk. 1997).

Ketiga, Ngurah (2010) dalam disertasinya yang berjudul "Dialog Antar Umat Beragama Dalam Masyarakat Multikultural Di Kota Denpasar", menyatakan dalam tulisannya bahwa dialog antarumat beragama dalam masyarakat multikultur Kota Denpasar telah dikaji mengenai landasan apa yang dipakai untuk dialog, faktor apa yang dipakai sebagai pendorong dan penghambat untuk berdialog, apa pula dampak serta makna dialog antarumat beragama di Kota Denpasar. Di samping itu, penelitian ini juga menggali dan mengkaji ideologi yang ada di balik ideologi multikulturalisme. Kenyataannya yang terjadi di masyarakat, di satu sisi dialog berjalan terus-menerus dan di sisi lain konflik ataupun gejala konflik selalu ada. Di Kota Denpasar hal ini dapat diredam, sehingga tidak meluas. Konflik dan gejala konflik mengganggu kerukunan umat beragama yang telah dipupuk selama ini dan jika tidak ada penanganan yang cermat dan tepat, kondisi demikian dapat menjadi pemicu konflik SARA dan disintegrasi bangsa, terutama bagi masyarakat beragama di Kota Denpasar (Ngurah, 2010). Cara untuk meredam semua ini melalui semboyan "Bhineka Tunggal Ika".

Keempat, Arsana (2006) dalam tesisnya yang berjudul "Segregasi Sosial dan Pola Adaptasi Budaya Dalam Kehidupan Pluralisme Agama Di Desa Dalung, Kecamatan Kuta Utara, Kabupaten Badung" menyatakan bahwa penelitian ini berangkat dari adanya isu mengenai terjadinya fenomena pemisahan sosial (social 
segregation) terhadap sejumlah warga komunitas di desa tersebut yang berubah sistem keyakinan beragamanya menjadi pemeluk agama Kristen. Latar belakang alasan untuk memisahkan warga yang memeluk agama Kristen itu terutama disebabkan oleh adanya sistem tatanan kehidupan komunal (desa adat) yang menganut landasan teosofi Hindu yang bersifat homogin. Sistem tatanan kehidupan komunal seperti itu selanjutnya memunculkan semacam pandangan budaya yang lebih mengedepankan 'absolutisme identitas', yaitu identitas yang dipandang sebagai sebuah kepastian yang sudah 'given', yang sakral, tidak boleh diubah serta tidak boleh dicampuri oleh unsur-unsur identitas yang lainnya. Pandangan budaya yang terbentuk dalam sistem tatanan komunal memiliki kecenderungan untuk menafikan pluralisme agama. Berdasarkan prinsip dasar sistem tatanan komunal tersebut diasumsikan dapat menyebabkan warganya yang berubah sistem keyakinan agama mengalami proses-proses reposisi sosial seperti, perubahan status dan peranannya dalam sistem kehidupan komunal, baik di desa adat, banjar, maupun juga dalam kehidupan sistem klan. Dalam penelitian ini secara garis besar menemukan bahwa teosofi Hindu yang menjadi tatanan dasar dalam sistem kehidupan komunal memunculkan prinsip sistem komunal yang bersifat homogin, sehingga berkecenderungan untuk menafikan pluralisme agama. Hasil studi juga menemukan bahwa terdapat dua varian yang mewarnai pandangan budaya komunal untuk memaknai pluralisme agama yang berkembang di dalam sistem kehidupan masyarakat di Desa Dalung, seperti: ada yang memandangnya sebagai fenomena keterputusan (discontinuity) hubungan rantai kultural antara warga yang beragama Hindu dengan yang beragama Kristen. Di sisi kehidupan komunal lainnya, ada yang dapat memandangnya sebagai tanda keterputusan yang masih dapat disambung kembali (reconnection) untuk meneruskan kembali (recontinuity) hubungan kultural di antara warga yang berbeda agama. Adanya varian pandangan budaya seperti itu dapat mempengaruhi pola-pola adaptasi dan pertukaran budaya (culture exchange) dalam kehidupan masyarakat pluralisme di Desa Dalung (2006).

Kelima, Suwitha (2015) dalam Jurnal Jnana Budaya yang berjudul "Aktualisasi Nilai-Nilai Menyama Braya Dalam Membangun Masyarakat Multikultur di Pedesaan Bali" mengungkapkan bahwa kehidupan multikultur masyarakat pedesaan Bali yang multietnis dan multiagama menunjukkan solidaritas, toleransi dan integrasi yang tinggi. Terjadi pertukaran dan penyerapan budaya dalam berbagai aktivitas kehidupan antarmasyarakat yang berlainan agama dan etnis.

\section{SIMPULAN DAN SARAN Simpulan}

Kebudayaan lokal yang mengandung pesanpesan kearifan lokal berdasarkan kesepakatan masyarakat merupakan prasyarat mutlak dalam mempertahankan harmonisasi antaranggota masyarakat majemuk. Demikian pula aspek agama juga mengandung pesan-pesan moral yang bersumber dari dogma agama. Seperti halnya yang terjadi dalam etnis Donggo yang bertempat tinggal di Desa Mbawa, Kecamatan Donggo, Kabupaten Bima, NTB. Dengan mengedepankan kearifan lokal sebagai strategi kebudayaan dalam mewujudkan toleransi beragama nyatanya telah mampu mengurangi konflik yang dilatarbelakangi agama.

Sebagai warga negara sudah tidak ada pilihan dan harus bersedia untuk saling menerima dalam perbedaan. Para tokoh agama, tokoh masyarakat dan pemegang kebijakan dalam agama dan kebudayaan perlu mempertimbangkan dan mendialogkan kearifan lokal sebagai strategi toleransi beragama, karena sikap dan kebijakan seperti itu akan mendatangkan manfaat, diantaranya: 1) Melestarikan kebudayaan lokal/daerah seperti penyelenggaraan upacara Raju. Penyelenggaraan upacara ini sangat efektif untuk membangun kesadaran sosial dan emosi keyakinan yang diwariskan oleh para leluhur; 2) Memperkenalkan (mempro- 
mosikan) kebudayaan lokal (daerah) sebagai budaya kreatif. Penyelenggaraan upacara Raju setiap tahun dapat dijadikan kegiatan tahunan untuk menghadirkan wisatawan ke Desa Mbawa; 3) Menghargai karya leluhur terutama yang memiliki nilai budaya yang positif dan progresif seperti Ume Leme (rumah runcing) sebagai media atau simbol integrasi dan toleransi yang mengkerucutkan ke satu arah dalam hal ini adalah Tuhan yang mengandung nilai sakral dari pemeluk agama Islam, Khatolik dan Protestan yang ada di Desa Mbawa; dan 4) Mentradisikan pemberian nama dapat mengangkat martabat dari peradaban lama untuk masa depan, memperkuat jati diri dan pembentukan karakter, sebagai media pendidikan multikultur dan multiagama.

\section{Saran}

Kasus kearifan lokal, tradisi pemberian nama, penyelenggaraan Upacara Raju dan memusatkan penyelenggaraan upacara di Uma Leme dapat mewujudkan integrasi dan toleransi beragama yang terjadi di Desa Mbawa perlu diapresiasi dan diaplikasikan di tempat lain di Indonesia. Dapat dipastikan bahwa tidak sedikit penduduk di daerah lain di Indonesia yang penduduknya multietnik, budaya, dan agama.

Pemerintah sebagai pemegang kebijakan, baik dalam bidang kebudayaan dan agama perlu kiranya membuat gerakan program mengenai akulturasi dan relasi yang berkaitan dengan kedua hal tersebut. Sebaliknya perlu ada dialog antara tokoh-tokoh agama yang ada dengan tokoh kebudayaan lokal dengan membahas bentuk pengakuan akan otonomi agama-agama dan otonomi budaya, sehingga wilayah agama dan wilayah budaya tidak dicampuradukkan. Namun perlu dicatat bahwa bila terjadi hubungan (relasi) antara kebudayaan dan agama bukan berarti nilai agama diturunkan kesakralannya. Begitu juga sebaliknya, nilai kebudayaan tidak harus diangkat sama derajat kesuciannya dengan nilai agama.

\section{PUSTAKA ACUAN}

Armini, A. I.G. 2013. Toleransi Masyarakat Multi Etnis dan Multi Agama Dalam Organisasi Subak Di Bali, Jurnal Penelitian Sejarah dan Budaya Patanjala, 5(1), 48-49.

Arsana, I.G.K.G. 2006. Segregasi Sosial Dan Pola Adaptasi Budaya Dalam Kehidupan Pluralisme Agama Di Desa Dalung, Kecamatan Kuta Utara, Kabupaten Badung. Tesis (tidak dipublikasikan). Denpasar: Program Pasca Sarjana Universitas Udayana.

Confido, J.V. 2015. 7 Tingkatkan Strategi. Lionmag (22-23).

Dhana, N., Agung A A G P, Parimartha I G, Geriya W, \& Sudarma W. 2002. Integrasi Antaretnik Berbeda Agama Melalui Upacara Agama Kajian Tentang Hubungan Antaretnik Bali dan Sasak Melalui Upacara Perang Topat di Pura Lingsar Lombok. Denpasar: Balai Kajian Sejarah dan Nilai Tradisional.

Fatmawati, I. 2014. Efektivitas Buah Lerak (Sapindus Rarak De Candole) Sebagai Bahan Pembersih Logam Perak, Perunggu dan Besi. Jurnal Konservasi Cagar Budaya Borobudur. 8(2) 23-30.

Huntington, S.P. 1996. The Clash Of Civilisations and The Remaking Of The World Order. New York: Touchstone Book.

Marjanto, D, K. 2015. Kearifan Lokal Upacara Ruwatan Rambut Gembel dan Hubungannya Dengan Pelestariann Lingkungan di Kawasan Dieng. Jurnal Penelitian Sejarah dan Nilai Tradisional, 22(2) 279-304.

Ngurah, I.G.M. 2010. Dialog Antar Umat Beragama Dalam Masyarakat Multikultural Di Kota Denpasar. Disertasi. Denpasar: Program Pascasarjana Universitas Udayana. 
Peursen, V.C.A. 1989. Strategi Kebudayaan. Yogyakarta: Penerbit Kanisius. Edisi Kedua.

Purna, I. M. 2001. Budaya Masyarakat Perbatasan Studi Kasus Desa Pegayaman Buleleng, Jurnal Penelitian Sejarah dan Nilai Tradisional. 2(2) 34-38.

Purna, I, M. 2007. Pendidikan Ideologi Multikultural Dalam Ketahanan Budaya Bangsa Indonesia (dalam Analisis SWOT). Jurnal Jnana Budaya. XI(11) 1-11.

Purwanto, S.A, ed. 2015. Revolusi Mental Sebagai Strategi Kebudayaan. Jakarta: Pusat Penelitian dan Pengembangan Kebudayaan.

Satyananda, I M. 2015. Rumah Tradisional Donggo. Jurnal Jnana Budaya. 20(2) 247-264.

Situmorang, R.O.P. \& Simanjuntak, E.R. 2015. Kearifan Lokal Pengelolaan Hutan oleh Masyarakat Sekitar Kawasan Taman Wisata Alam Sicike-Cike, Sumatera Utara. Jurnal Widyariset. 18(1) 145-153.

Sudarma, I. W. 2001. Budaya Masyarakat dan Potensi Konflik dalam Perspektif Multikulturalisme. Jurnal Jnana Budaya Edisi Kesebelas. XI(11) 41-43.

Sudarma, I. W. 2007. Kajian Antaretnik dalam Pelaksanaan Upacara Tradisional di Pura Subak Medewi Jembrana. Jurnal Penelitian Sejarah dan Nilai Tradisional, I(1) 122-125.

Sudjiono, A. 2009. Pengantar Evaluasi Pendidikan. Jakarta: PT Raja Grafindo Persada.

Suwitha, I, G, P. 2015. Aktualisasi Nilai-Nilai Menyama Braya dalam Membangun Masyarakat Multikultur di Pedesaan Bali. Jurnal Jnana Budaya. 20(2) 163-179.

Tule, P.S.V.D. 2010. Wahana Harmonisasi Masyarakat Melalui Pembangunan dan Kesejahteraan, dalam Buku Industri Budaya-Budaya Industri. Jakarta: Kementerian Kebudayaan dan Pariwisata.

Wajidi. 2014. Hubungan Islam dan Budaya dalam Tradisi Ba-Ayun Maulid di Masjid Banua Halat Kabupaten Tapin, Kalimantan Selatan. Jurnal Penelitian Sejarah dan Budaya Patanjala, 6(3) 350-354. 